\title{
Replacement of soybean meal by cottonseed meal in diets based on spineless cactus for lactating cows ${ }^{1}$
}

\author{
Fabiana Maria da Silva ${ }^{2}$, Marcelo de Andrade Ferreira ${ }^{3}$, Adriana Guim ${ }^{3}$, Ricardo Alexandre \\ Silva Pessoa ${ }^{3}$, Luiz Henrique dos Santos Gomes ${ }^{4}$, Júlio César Vieira de Oliveira ${ }^{5}$
}

\footnotetext{
${ }^{1}$ Trabalho realizado pelo acordo UFRPE/IPA e financiado pelo CNPq.

2 Programa de Pós-Graduação em Zootecnia da UFRPE - Recife, PE.

${ }^{3}$ Departamento de Zootecnia/UFRPE. Bolsista do CNPq

${ }^{4}$ IC-CNPq/UFRPE.

5 IPA.
}

ABSTRACT - The objective of this study was to evaluate the replacement of soybean meal by cottonseed meal in the diet of dairy cows fed diets based on spineless cactus. Five Girolando lactating cows were used, with average live weight of $490 \mathrm{~kg}$ and average production of $11.5 \mathrm{~kg}$ of milk/day, distributed in a $5 \times 5$ Latin square design ( 5 animals, 5 treatments and 5 experimental periods). Each experimental period lasted 15 days, 10 days being for the adaptation of the animals to the diet and 5 days for data collection. The experimental diet consisted of spineless cactus (53\%), sorghum silage (32\%) and concentrate (15\%). The cottonseed meal replaced $0,25,50,75$ and $100 \%$ of soybean meal in the concentrate. The intake, milk yield and composition were evaluated. The nutrients intake and digestibility were not affected by the treatments, with an average of 15.55 and 56.05; 13.8 and 59.31, 0.37 and 49.40, 5.32 and 30.95, 1.79 and 48.14; 9.94 and 54.31, 4.43 kg/day and 80.99\%, for the dry matter, organic matter, ether extract, neutral detergent fiber, crude protein, total carbohydrates and non-fibrous carbohydrates, respectively. The total digestible nutrients were not affected (average of $8.30 \mathrm{~kg} /$ day). Similarly, the milk yield and composition, fat corrected milk yield (4\%), lactose, total solids, fat and protein were not affected by replacement (11.56, $11.41 \mathrm{~kg}$ milk/day and 4.45, 12.75, 3.95 and 3.42\%, respectively). Recommended the replacement of soybean meal by cottonseed meal for low production dairy cows.

Key Words: concentrate, dairy cows, protein

\section{Substituição do farelo de soja pelo farelo de algodão em dietas à base de palma forrageira para vacas em lactação}

\footnotetext{
RESUMO - Objetivou-se avaliar a substituição do farelo de soja pelo farelo de algodão em dietas à base de palma forrageira para vacas em lactação. Foram utilizadas cinco vacas da raça Girolando (peso vivo médio de 490 kg e produção média de $11,5 \mathrm{~kg}$ de leite/dia), distribuídas em um quadrado latino $5 \times 5$, composto de cinco animais, cinco níveis de farelo de algodão (0; 25; 50; 75 e 100\%) em substituição ao farelo de soja e cinco períodos experimentais, cada um com 15 dias de duração (10 dias para adaptação e 5 dias para coleta de dados e amostras). As dietas experimentais foram constituídas de palma forrageira (53\%), silagem de sorgo (32\%) e concentrado (15\%). A inclusão do farelo de algodão não influenciou o consumo e a digestibilidade dos nutrientes, cujas médias foram de $15,55 \mathrm{~kg} /$ dia e 56,05\% para matéria seca (MS); 13,84 kg/dia e 59,31\% para matéria orgânica (MO); 0,37 kg/dia e 49,40\% para extrato etéreo; 5,32 kg/dia e 30,95\% para fibra em detergente neutro; 1,79 kg/dia e 48,14\% para proteína bruta; $9,94 \mathrm{~kg} /$ dia e 54,31\% para carboidratos totais; e 4,43 kg/dia e 80,99\% para carboidratos não-fibrosos. O consumo de nutrientes digestíveis totais também não foi influenciado (média de 8,30 kg/dia) pela substituição do farelo de soja pelo farelo de algodão. Igualmente, a produção e composição do leite também não foram afetadas e apresentaram médias de 11,56; 11,41, kg leite/dia e 4,45; 12,75; 3,95 e 3,42\% para produção de leite, produção de leite corrigida para 4\% de gordura, teores de lactose, sólidos totais, gordura e proteína, respectivamente. Recomenda-se a substituição do farelo de soja pelo de algodão para vacas de baixa produção.
}

Palavras-chave: bovino de leite, concentrado, proteína 


\section{Introduction}

Traditional feed components, such as soybean meal, tend to increase the animal production costs due to either their being transported from other regions or being considered a commodity. Thus, the replacement of traditional foods with alternatives has become a common practice in the attempt to lower production costs. This is especially true for the northeastern Brazil semi-arid regions, where the low, irregular rainfall associated to high temperatures is particularly onerous regarding the acquisition of feed sources. However, rations formulated from alternative ingredients must be efficient and economical, while offering the same performance obtained from traditional diets. According to Valadares Filho et al. (2006), cottonseed meal as an alternative to soybean meal contains $68.31 \%$ total digestive nutrients, $38.03 \%$ crude protein (CP), 34.92\% neutral detergent fiber and $20.37 \%$ nonfibrous carbohydrates. It also has reasonable palatability and a lower cost (in absolute terms and per kg of CP) than soybean meal, thereby making its use in animal feed a viable alternative (Lana, 2000).

The spineless cactus (Opuntia fícus indica-Mill) has been used as an alternative feed source in northeastern Brazil due to its advantages of being highly resistant to the climatic conditions of the region and offering a satisfactory nutritional composition (Ferreira, 2005). Spineless cactusbased diets generally provide sufficient energy, especially for animals with low to moderate production, which diminishes the need for large amounts in the diet. According to Araújo et al. (2004), supplementation for cows with a mean production of up to $15 \mathrm{~kg} /$ day should be only protein and the cactus associated to a source of fiber that provides sufficient energy.

Pina et al. (2006) assessed the effects of different protein sources in the diet of lactating cows and found no differences in either nutrient intake or milk production.
Imaizumi et al. (2002), however, replaced soybean meal with cottonseed meal and found a reduction in milk production.

The objective of the present study was to assess the influence of replacing soybean meal by cottonseed meal corrected with urea in spineless cactus-based diets for lactating cows on nutrient intake and digestibility as well as milk production and composition.

\section{Material and Methods}

The present study was carried out from January to March 2008 at the Estação Experimental de Arcoverde, which belongs to the Instituto Agronômico de Pernambuco. The municipality of Arcoverde is located in the intermediate zone between the semi-arid savannah known as the agreste and the drier semi-arid region of the state of Pernambuco (northeastern Brazil) at $08^{\circ} 25^{\prime} 08^{\prime \prime} \mathrm{S}$ and $37^{\circ} 03^{\prime} 14 " \mathrm{~W}$ and $663 \mathrm{~m}$ above sea level (IBGE, 2005). Mean maximum and minimal temperatures during the period were 28.5 and $21.2^{\circ} \mathrm{C}$, respectively.

The diet without cottonseed meal was formulated to meet the needs of cows with a mean production of $12 \mathrm{~kg} /$ day. In the other diets, soybean meal was replaced with cottonseed meal (38\% CP) (Table 1).

Five multiparous Girolando cows (crossbred Hoister $\times$ Gyr - 5/8HG) with approximately 150 days of lactation, average of $490 \mathrm{~kg} \mathrm{BW}$ and average milk production of $11.5 \mathrm{~kg} /$ day were used. The animals were housed in individual stalls with a shaded area and uncovered area, with feeding and drinking troughs for the control of feed and water intake. The experimental design was a $5 \times 5$ Latin square with five cows, five soybean meal replacement levels and five periods. Each experimental period lasted 15 days - 10 days for cows adapt to the diet and five days for data and sample collections, for a total of 75 days. Feed was offered ad libitum twice a day ( 7 a.m. and 3 p.m.) in the form of total mixed ration (Tables 1 and 2). The spineless

Table 1 - Nutritional composition of the ingredients used in the experimental diets

\begin{tabular}{|c|c|c|c|c|}
\hline \multirow[t]{2}{*}{$\overline{\text { Item }}$} & \multicolumn{4}{|c|}{ Ingredient } \\
\hline & Soybean meal & Cottonseed meal & Cactus pear & Sorghum silage \\
\hline Dry matter (\%) & 89.50 & 90.98 & 18.76 & 28.55 \\
\hline Ash (\% DM) & 6.63 & 7.70 & 9.92 & 7.84 \\
\hline Crude protein (\%DM) & 49.55 & 40.90 & 1.93 & 5.96 \\
\hline Ether extract (\%DM) & 1.80 & 1.75 & 0.99 & 2.55 \\
\hline Neutral detergent fiber (\%DM) & 17.04 & 28.21 & 26.61 & 61.35 \\
\hline $\mathrm{NDF}_{\mathrm{cm}}(\% \mathrm{DM})^{2}$ & 16.68 & 27.62 & 25.85 & 58.50 \\
\hline Acid detergent fiber (\%DM) & 6.97 & 11.41 & 17.20 & 32.38 \\
\hline Total carbohydrates (\%DM) & 42.02 & 49.65 & 87.16 & 83.65 \\
\hline Non-fibrous carbohydrates (\%DM) & 24.97 & 21.44 & 60.99 & 22.30 \\
\hline $\mathrm{ADF}_{\mathrm{i}}(\% \mathrm{DM})$ & 0.40 & 9.05 & 9.72 & 12.19 \\
\hline
\end{tabular}

$\mathrm{NDF}_{\mathrm{cm}}=$ neutral detergent fiber corrected for ash and protein; $\mathrm{ADF}_{\mathrm{i}}=$ indigestible acid detergent fiber. 
Table 2 - Composition in ingredients and nutritional according to soybean meal replacement levels by cottonseed meal + urea in the experimental diets

\begin{tabular}{|c|c|c|c|c|c|}
\hline \multirow[t]{2}{*}{ Ingredient $(\%$ of $\mathrm{DM})$} & \multicolumn{5}{|c|}{ Soybean meal replacement level (\%) } \\
\hline & 0 & 25 & 50 & 75 & 100 \\
\hline Cactus pear & 53.0 & 53.0 & 53.0 & 53.0 & 53.0 \\
\hline Sorghum silage & 32.0 & 32.0 & 32.0 & 32.0 & 32.0 \\
\hline Cottonseed meal & 0.00 & 3.00 & 6.00 & 9.00 & 12.0 \\
\hline Urea & 0.75 & 0.84 & 1.03 & 1.12 & 1.31 \\
\hline Mineral mix & 1.24 & 1.24 & 1.24 & 1.24 & 1.24 \\
\hline Dry matter $(\%)$ & 24.21 & 24.23 & 24.24 & 24.26 & 24.30 \\
\hline Organic matter (\%DM) & 89.15 & 89.13 & 89.12 & 89.09 & 89.07 \\
\hline Ash (\%DM) & 10.85 & 10.87 & 10.88 & 10.91 & 10.93 \\
\hline Crude protein (\%DM) & 11.47 & 11.46 & 11.51 & 11.48 & 11.50 \\
\hline Ether extract (\%DM) & 5.16 & 5.15 & 5.15 & 5.14 & 5.13 \\
\hline Neutral detergent fiber (\%DM) & 35.92 & 36.25 & 36.52 & 36.84 & 37.16 \\
\hline
\end{tabular}

1 Estimated by digestible essay.

2 Neutral detergent fiber corrected for ash and protein.

cactus was processed in a specific fodder machine designed for cactus.

In each collection period, samples were taken of the feed and orts, which were weighed and dried in a forced ventilation over at $60^{\circ} \mathrm{C}$ for 48 hours at the Estação Experimental de Arcoverde. Feces were collected on the 11th and 15th days of each experimental period prior to the morning and afternoon milking, respectively, weighed and dried in a forced ventilation over at $60^{\circ} \mathrm{C}$ for 72 hours, also at the Estação Experimental de Arcoverde.

At the end of each experimental period, a sample consisting of orts and feces per period and per animal was determined. These samples were ground in a Willey mill (knife blades) and passed through a 2-mm sieve for subsequent analysis of indigestible acid detergent fiber (ADFi). A portion was then passed through a 1-mm sieve for the remaining analyses. The samples were stored in labeled plastic containers until analysis.

The analyses of dry matter (DM), mineral matter $(\mathrm{MM})$, total nitrogen $(\mathrm{N})$ and ether extract (EE) followed the recommendations described by Silva \& Queiroz (2002). For the determination of the components of the fiber cell wall in neutral detergent fiber (NDF) and acid detergent fiber (ADF), the methods described by Van Soest et al. (1991) were used, but using cloth-non-cloth bags made at the Laboratório de Nutrição Animal of the Universidade Federal Rural de Pernambuco (Brazil), using an autoclave. For the NDF analysis of the orts, feed and spineless cactus, three drops (50 $\mu \mathrm{L}$ ) of $\alpha$-amylase were added per sample at the time of washing with detergent and then with water. In the
NDF analysis, protein and ash content in the residuals were determined in order to obtain the neutral detergent fiber corrected for ash and protein $\left(\mathrm{NDF}_{\mathrm{ap}}\right)$.

The total carbohydrate (TC) content was calculated based on the method described by Sniffen et al. (1992), in which TC $=100-(\mathrm{CP} \%+\mathrm{EE} \%+$ Ash\% $)$. The non-fibrous carbohydrate (NFC) content was estimated based on the method described by Mertens (1997), in which NFC $=100$ [NDF\% +EE\% + CP\% + MM\%].

The intake of total digestible nutrients (TDN) was calculated based on the equation proposed by Sniffen et al. (1992): $\mathrm{TDN}=\mathrm{CPI}_{\mathrm{D}}+\mathrm{TCI}_{\mathrm{D}}+\left(2.25 \times \mathrm{EEI}_{\mathrm{D}}\right)$, in which: $\mathrm{CPI}_{\mathrm{D}}=$ digestible crude protein intake, $\mathrm{TCI}_{\mathrm{D}}=$ total digestible carbohydrate intake and $\mathrm{EEI}_{\mathrm{D}}=$ digestible ether extract intake.

The production of fecal dry matter for the estimate of the apparent digestibility of the nutrients was estimated from the concentrations of indigestible acid detergent fiber (ADFi) obtained following rumen incubation of the feeds, orts and feces for 264 hours (Casali et al., 2008): $1.0 \mathrm{~g}$ of feed concentrate and spineless cactus and $0.5 \mathrm{~g}$ of the sorghum silage, orts and feces. The samples were then removed from the rumen, washed and submitted to ADF analysis for the determination of the fraction of remaining fiber (ADFi). Fecal dry matter production (FDMP) was estimated from the intake of the indicator divided by its respective concentration in the feces. The apparent digestibility coefficient (ADC) was calculated based on the equation described by Silva \& Leão (1979): ADC = (ingested nutrient - excreted nutrient / ingested nutrient) $\times 100$. 
The cows were milked twice a day ( 5 a.m. and 1 p.m.) and their production was recorded individually. Milk production was corrected for $4 \%$ fat (MPCF) using the equation MPCF $=0.4 \times(\mathrm{kg}$ milk $)+15 \times(\mathrm{kg}$ fat $)$ [American National Research Council (NRC), 1989]. Milk samples were collected on the 15th day of each experimental period proportional to the morning and afternoon production ( $2 \%$ of the production). From this sample, an approximately 50-mL aliquot was removed, to which bronopol was added as a conservative. This sample was sent to the PROGENE laboratory (Management of Milk-Producing Herds of Northeastern Brazil) located in the Departamento de Zootecnia of the Universidade Federal Rural de Pernambuco (Brazil), where the content of fat (FAT), protein (PROT), lactose (LACT) and total solids (ST) was determined. Feeding efficiency was computed for each cow, dividing mean milk production by mean DM intake for each experimental period (Valadares Filho et al., 2000).

The data were submitted to analysis of variance and regression analysis, considering the soybean meal replacement levels in the experimental diets. The SAEG software program (Sistema de Análise Estatística e Genética) (UFV, 1998) was used for the data analysis, with the level of significance set at $5 \%$.

\section{Results and Discussion}

The intake of dry matter (DM) [kilograms per day (kg/day), percentage of body weight (\%BW) and metabolic weight $\left.\left(\mathrm{g} / \mathrm{kg}^{0.75}\right)\right]$, organic matter $(\mathrm{OM})$, ether extract (EE), neutral detergent fiber (NDF), crude protein (CP), non-fibrous carbohydrates (NFC), total carbohydrates (TC) and total digestible nutrients (TDN - kg/day) was not influenced by the replacement of soybean meal by cottonseed meal in the $\operatorname{diet}(\mathrm{P}>0.05)$. Among the factors that may affect DM intake, those that could be influenced by the replacement of soybean meal by cottonseed meal would be palatability and composition. According to Lana (2000), cottonseed meal has good palatability and may completely replace soybean meal in diets for cows. The composition was unaltered, especially the NDF and NFC content. Other components that could affect intake would be the percentages of $\mathrm{CP}$ and $\mathrm{ADFi}$, which were also maintained constant among the experimental diets (Table 2). The intake of OM, EE, CP, NDF, NFC, TC and TDN (kg/day) were unaltered, as there was no difference in DM intake and the proportions were quite similar between diets (Table 2).

Similar performance was described by Pina et al. (2006), who studied different sources of protein for lactating cows, as well as by Imaizumi et al. (2002), who analyzed increasing levels of cottonseed meal in the diet of Holstein cows. Providing spineless cactus-based diets with a low protein concentrate content, Araújo et al. (2004) also observed no influence of the treatments on the nutrient intake. Van Horn et al. (1979) analyzed different sources of protein (cottonseed meal and soybean meal) and different CP levels in the diet (13.5 and 16.3\%) and reported an increase in DM intake in both treatments; however, this increase was more significant when the protein source was cottonseed meal.

At all levels of cottonseed meal, the DM intake was higher than the requirements established by the NRC (2001) for animals with a similar production level (14.42 kg/day). The NRC itself reported that, after the 10th week of lactation, the use of the equation to estimate intake may actually underestimate it. Regarding CP, the NRC (2001) estimates the requirement to be $1.69 \mathrm{~kg} / \mathrm{day}$. In the present study, mean CP intake was $1.79 \mathrm{~kg} /$ day, which was slightly higher than NRC estimate. The TDN intake ( $8.30 \mathrm{~kg} /$ day) was also higher than that estimated by the NRC ( $7.32 \mathrm{~kg} /$ day). As the diets were based on spineless cactus, the results supported statements by Araújo et al. (2004) that spineless cactusbased diets can provide a large portion of the energy for cows with low to moderate milk production.

As for the intake of nutrients (Table 3), there was no change in the apparent digestibility coefficient of the nutrients $(\mathrm{P}>0.05)$ with the replacement of soybean meal by cottonseed meal (Table 4), which was probably due to the similarity in the experimental diets. According to Church (1993), one of the most important factors that can influence digestibility is the diet composition. Although cottonseed meal has a greater amount of components considered indigestible (ADFi) compared to soybean meal (Table 2), the level of inclusion of this ingredient in the present study was low and there was little difference in the percentage of this component in the experimental diets (mean value of 9.33\%).

According to Van Soest (1994), Ørskov (2000) and McDonald et al. (2002), other factors that could affect the nutrient digestibility would be feed intake, the proportion and degradability of the cell wall, the composition of the feed component, feed composition, feed preparation, protein-to-energy ratio, rate of degradability and factors inherent to the animal. As there was no difference in the apparent digestibility coefficient, these factors were probably satisfied and/or maintained.

This performance differed from that described by Pina et al. (2006), who reported lower digestibility values for DM, OM, EE, CP and NDF when analyzing the use of 
cottonseed meal compared to soybean meal. However, these authors used higher levels of these components in diets provided to pure-bred animals with greater milk production.

Milk production and composition were unaltered by the replacement of soybean meal with cottonseed meal (Table 5). Milk production may not have been affected by the fact that the intake of dry matter and other nutrients was not affected by the soybean meal replacement by cottonseed meal. As the animals used were of low milk production, their requirements were met, despite the low levels of soybean meal and cottonseed meal offered, as can be seen in relation to the intake of DM, CP and TDN estimated by the NRC (2001) and that found in the present study.
Milk composition also varied little between diets. Diet composition is one of the factors that most affect the milk composition, especially NDF and NFC content, which were very similar between diets in the present study (Table 2).

Results for milk production and composition differed from those reported by Imaizumi et al. (2002), who found a decrease in milk production as well as fat, lactose and protein content in the milk when replacing soybean meal with cottonseed meal for lactating Holsteins. However, these authors studied pure-bred cows with a greater production (mean of $32 \mathrm{~kg}$ of milk/day) and suggested that the drop in production may have been caused by the availability of lysine and methionine, which may have been

Table 3 - Intake of nutrients at each level of soybean meal replacement levels by cottonseed meal + urea in the experimental diets

\begin{tabular}{|c|c|c|c|c|c|c|c|}
\hline \multirow[t]{2}{*}{ Item } & \multicolumn{5}{|c|}{ Soybean meal replacement level (\%) } & \multirow[t]{2}{*}{ Regression equation } & \multirow[t]{2}{*}{ CV $(\%)$} \\
\hline & 0 & 25 & 50 & 75 & 100 & & \\
\hline Dry matter (kg/day) & 15.26 & 15.21 & 16,21 & 15.06 & 16.03 & $\hat{Y}=15.55$ & 7.32 \\
\hline Dry matter (\%BW) & 3.15 & 3.21 & 3.39 & 3.21 & 3.34 & $\hat{Y}=3.26$ & 7.09 \\
\hline Dry matter $\left(\mathrm{g} / \mathrm{kg}^{0,75}\right)$ & 147.72 & 149.62 & 158.55 & 149.23 & 156.26 & $\hat{Y}=152.27$ & 7.06 \\
\hline Ether extract (kg/day) & 0.36 & 0.36 & 0.39 & 0.36 & 0.36 & $\hat{\mathrm{Y}}=0.37$ & 6.70 \\
\hline Organic matter (kg/day) & 13.59 & 13.51 & 14.43 & 13.41 & 14.25 & $\hat{Y}=13.84$ & 2.03 \\
\hline Neutral detergent fiber (kg/day) & 5.30 & 5.39 & 5.75 & 5.40 & 5.76 & $\hat{Y}=5.52$ & 7.64 \\
\hline $\mathrm{NDFI}_{\mathrm{cm}}$ (kg/day) & 5.10 & 5.20 & 5.55 & 5.20 & 5.54 & $\hat{Y}=5.32$ & 7.60 \\
\hline Crude protein (kg/day) & 1.74 & 1.73 & 1.88 & 1.72 & 1.87 & $\hat{\mathrm{Y}}=1.79$ & 7.07 \\
\hline Non-fibrous carbohydrates (kg/day) & 4.49 & 4.35 & 4.62 & 4.20 & 4.47 & $\hat{Y}=4.43$ & 7.13 \\
\hline Total carbohydrates (kg/day) & 9.78 & 9.74 & 10.37 & 9.60 & 10.23 & $\hat{Y}=9.94$ & 7.32 \\
\hline Total digestible nutrient (kg/day) & 8.10 & 7.84 & 8.56 & 8.15 & 8.84 & $\hat{Y}=8.30$ & 9.79 \\
\hline
\end{tabular}

Table 4 - Apparent nutrient digestibility coefficients, regression equations and coefficients of variation (CV) at each level of soybean meal replacement level by cottonseed meal + urea in the experimental diets

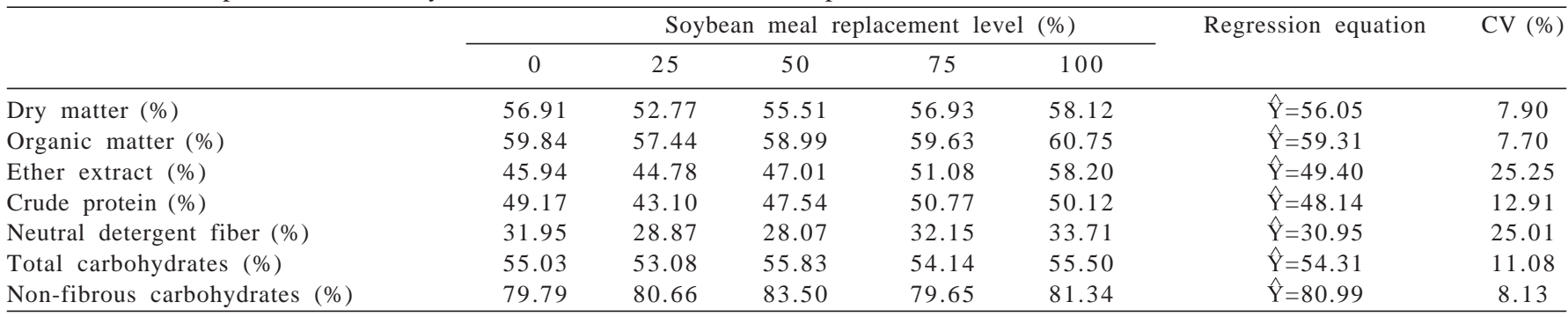

Table 5 - Milk production and composition, feeding efficiency, regression equations and coefficient of variation (CV) at each level of soybean meal replacement level by cottonseed meal + urea

\begin{tabular}{|c|c|c|c|c|c|c|c|}
\hline \multirow[t]{2}{*}{ Item } & \multicolumn{5}{|c|}{ Soybean meal replacement level (\%) } & \multirow[t]{2}{*}{ Regression equation } & \multirow[t]{2}{*}{ CV (\%) } \\
\hline & 0 & 25 & 50 & 75 & 100 & & \\
\hline Milk yield (kg/day) & 11.43 & 11.82 & 11.73 & 11.40 & 11.36 & $\hat{Y}=11.55$ & 3.99 \\
\hline FCMI (kg/day) & 11.54 & 11.56 & 11.69 & 10.81 & 11.46 & $\hat{\mathrm{Y}}=11.41$ & 8.69 \\
\hline Lactose $(\%)$ & 4.40 & 4.48 & 4.43 & 4.48 & 4.44 & $\hat{\mathrm{Y}}=4.45$ & 1.78 \\
\hline Total solids (\%) & 12.87 & 12.71 & 12.87 & 12.40 & 12.80 & $\hat{Y}=12.75$ & 3.93 \\
\hline Fat $(\%)$ & 4.06 & 3.89 & 4.07 & 3.70 & 4.05 & $\hat{Y}=3.95$ & 11.89 \\
\hline Protein (\%) & 3.47 & 3.46 & 3.43 & 3.34 & 3.41 & $\hat{Y}=3.42$ & 3.00 \\
\hline
\end{tabular}

FCMY = fat corrected milk yield ( $4 \%$ fat). 
offered in limited amounts when using the cottonseed meal. Van Horn et al. (1979) studied different protein sources (cottonseed meal and soybean meal) and different CP levels in the diet (13.5 and 16.3\%) and reported no influence of the source or level of CP on milk production. Pina et al. (2006) observed no differences in milk production or composition when studying four different protein sources for Holstein cows with an average milk production of $25 \mathrm{~kg} /$ day.

Considering the prices on the market based on dry matter: [soybean meal = R\$1.13; cottonseed meal $=\mathrm{R} \$ 0.84$; urea $=\mathrm{R} \$ 1.50$ (price per kg of the ingredient)], there was a reduction of approximately $22 \%$ in the cost per kg o of the protein concentrate with the increase in the level of cottonseed meal. Another important fact is that the milk production $/ \mathrm{kg}$ of protein concentrate ratio was well above (mean of 5.14:1) that practiced by producers in the region (3 kg of milk for every $\mathrm{kg}$ of protein concentrate).

\section{Conclusions}

The replacement of soybean meal by cottonseed meal does not alter nutrient intake, nutrient digestibility, milk production or milk composition in Girolando cows. Thus, the replacement of soybean meal by cottonseed meal corrected with urea is recommended for low-production cows that consume spineless cactus-based diets.

\section{Literature Cited}

ARAÚJO, P.R.B.; FERREIRA, M.A.; BRASIL, L.H.A. et al. Substituição do milho por palma forrageira em dietas completas para vacas em lactação. Revista Brasileira de Zootecnia, v.33, n.6, p.1850-1857, 2004 (supl. 1).

CASALI, A.O.; DETMANN, E.; VALADARES FILHO, S.C. et al. Influência do tempo de incubação e do tamanho de partículas sobre os teores de compostos indigestíveis em alimentos e fezes bovinas obtidos por procedimentos in situ. Revista Brasileira de Zootecnia, v.37, n.2, p.335-342, 2008.

CHURCH, D.C. The ruminant animal. Digestive physiology and nutrition. Illinois: Waveland Press Inc., 1993. 564p.

FERREIRA, M.A. Palma forrageira na alimentação de bovinos leiteiros. Recife: UFRPE. Impressa Universitária. 2005. 68p.

INSTITUTO BRASILEIRO DE GEOGRAFIA E ESTATÍSTICA IBGE. [2005]. Pesquisa pecuária municipal. Disponível em: $<$ http://www.ibge.org.br>. Acesso em: 30/5/2008.
IMAIZUMI, H.; SANTOS, F.A.P.; VOLTONI, T.V. et al. Utilização de farelo de algodão como substituto do farelo de soja em dietas para vacas holandesas em lactação. In: REUNIÃO ANUAL DA SOCIEDADE BRASILEIRA DE ZOOTECNIA, 39., 2002, Recife. Anais... Recife: Sociedade Brasileira de Zootecnia, 2002. (CD-ROM).

LANA, R.P. Sistema Viçosa de formulação de rações. Viçosa, MG: Universidade Federal de Viçosa, 2000.

McDONALD, P.; EDWARDS, R.A.; GREENHALGH, J.F.D. et al. Animal nutrition. 6.ed. London: Pearson Prentice Hall, 2002. 693p.

MERTENS, D.R. Creating a system for meeting the fiber requeriments of dairy cows. Journal of Dairy Science, v.80, n.8, p.1463-1469, 1997.

NATIONAL RESEARCH COUNCIL - NRC. Nutrient requeriments of the dairy cattle. 6.ed. Washington, D.C.: Nacional Academic Press 1989. 158p.

NATIONAL RESEARCH COUNCIL - NRC. Nutrient requirement of the dairy cattle. 7.ed. Washington, D.C.: Nacional Academic Press, 2001. 363p.

ØRSKOV, E.R. New concepts of feed evaluation for ruminants with emphasis on roughases and feed intake. Asian-Australasian Journal of Animal Science, v.13, p.128-136, 2000.

PINA, D.S.; VALADARES FILHO, S.C.; VALADARES R.F.D. et al Consumo e digestibilidade aparente total dos nutrientes, produção e composição do leite de vacas alimentadas com dietas contendo diferentes fontes de proteína. Revista Brasileira de Zootecnia, v.35, n.4, p.1543-1551, 2006.

SILVA, D.J.; QUEIROZ, A.C. Análise de alimentos (métodos químicos e biológicos). 3.ed. Viçosa, MG: Universidade Federal de Viçosa, 2002. 235p.

SILVA, J.F.C.; LEÃO, M.I. Fundamentos de nutrição de ruminantes. Piracicaba: Livroceres, 1979. 380p.

SNIFFEN, C.J.; O'CONNOR, J.D., VAN SOEST, P.J. et al. A net carbohydrate and protein availability. Journal of Dairy Science, v.70, n.11, p.3562-3577, 1992.

UNIVERSIDADE FEDERAL DE VIÇOSA - UFV. Sistema de análise estatística e genética - SAEG. Versão 8.0. Viçosa, MG, 1998. 150p. (Manual do usuário).

VALADARES FILHO, S.C; BRODERICK, G.A; VALADARES, R.F.D. et al. Effect of replacing alfafa silage with high moisture corn $n$ nutriente utilization and milk production. Journal of Dairy Science, v.83, n.1, p.106-114, 2000.

VALADARES FILHO, S.C; MAGALHÃES, K.A.; ROCHA JR., V.R. et al. Tabelas brasileiras de composição de alimentos para bovinos. 2.ed. Viçosa, MG: Universidade Federal de Viçosa, 2006. 329p.

Van HORN, H.H.; ZOMETA, C.A; WILCOX, C.J. et al. Complete rations for dairy cattle. VIII. Effect of percent and source of protein on milk yield and ration digestibility. Journal of Dairy Science, v.62, n.7, p.1086-1093, 1979.

Van SOEST, P.J. Nutritional ecology of the ruminant. 2.ed Ithaca: Cornell University Press, 1994. 476p.

Van SOEST, P.J.; ROBERTSON, J.B.; LEWIS, B.A. Methods for extraction fiber, neutral detergent fiber and mostarch polysaccarides in relation to animal nutrition cows Journal of Dairy Science, v.83, n.10, p.3583-3597, 1991. 